KENESEI Zsófia ${ }^{1}$

\title{
KAPCSOLATI NORMÁK \\ JELENLÉTE A MAGYARORSZÁGI BANKOK ÉS VÁLLALATOK KÖZÖTT
}

A tranzakciós költségek elméletének Williamson által megfogalmazott piac vs. hierarchia dichotómiája mára a tudományos világban is elfogadott harmadik lehetôséggel bővült: a kapcsolati normákon keresztüli irányítás alternatívájával. A szerzó cikkében - a versenyképesség-kutatás adatbázisára támaszkodva - megvizsgálja, hogy a magyarországi kereskedelmi bankok mennyiben alkalmazzák a kapcsolati normákat a vállalati ügyfeleikkel fenntartott üzleti viszonyban, $s$ hogy az elmúlt évek során van-e változás e kapcsolatok jellegében.

Kulcsszavak: irányítási, kapcsolati normák, kapcsolatalapú, hierarchiaalapú irányítás, banki kapcsolatok

Noha a tranzakciós költségek elmélete (TCA) elsôsorban a vállalati „,vedd vagy csináld” dilemma leírására született, mégis az elmúlt 10-15 évben számos marketingprobléma megoldását a TCA eredményeinek alkalmazása tette lehetôvé (Rindfleisch - Heide, 1997). A TCA elemzési keretét felhasználó empirikus kutatások metaelemzése (Geyskens - Steenkamp - Kumar, 2006) arra is rámutatott, hogy a tranzakció-specifikus beruházások védelmére az eredeti williamsoni megoldások - a piac és a hierarchia - mellett egy harmadik, egyre gyakrabban megjelenő irányítási lehetôség is adódik. Az irányítási formák ezen harmadik típusa a szociológiából és a kapcsolati csere elméletéból kiindulva a kétoldalú kapcsolaton alapul. Az elmúlt évtizedekben felhalmozódott tapasztalatok alapján elmondható, hogy a kapcsolatalapú irányítási forma nagyon is valóságos helyettesítője a hierarchiának, olyankor, amikor a piac nem ad elegendő biztosítékot (Dyer, 1997).

\section{A kapcsolatiság jellemzói}

A kapcsolatalapú irányításra olyan esetben kerülhet sor, amikor a kapcsolat önmagában, külsô kényszerítô erố nélkül szabályozott, arra alapozva, hogy a szabályok betartása mindkét félnek érdeke, s ezért nem szükséges explicit módon kinyilvánítani azokat. (Természetesen ebben az esetben a szabályok valószínúleg olyanok, amelyek mindkét fél számára kedvezó lehetốségeket adnak.)
A kapcsolatoknak egy speciális területét, a formalizáltságot kiemelve ez olyan módon jelenhet meg, hogy míg a hierarchia által irányított viszonyokban explicit formában, írott, jól körülhatárolt szerződés rögzíti a kapcsolat minden pontját, addig a kapcsolatalapú irányítás esetében a kapcsolat bizonyos részeit nem szabályozzák, hanem normatív módon a felek jóérzésére hagyatkozva szabályozottak (Lusch - Brown, 1997).

Ez a két típusú irányítási forma (hierarchia és kapcsolatalapú), ahol létezik bármilyen nemú koordináció (szerzôdéses, bizalmon alapuló stb.), áll szemben a koordinációnélküliséggel, azaz a piac fennhatóságával (Heide, 1994). Mivel bizonyos esetekben - például bankok és vállalatok esetében - bizonyos koordináció mindenképpen szükséges, $\mathrm{s}$ a piac fennhatósága nem alternatíva, ezért ezekre a kapcsolatokra véleményünk szerint sokkal jellemzóbb a hierarchia vs. kapcsolati irányítás két végpontjával jellemezhető kontinuum, mint a piac-hierarchia kontinuum.

Kutatásunkban ennek megjelenését a kapcsolatiságkonstrukcióval kívánjuk mérni. A kapcsolatiság általunk használt fogalma a kapcsolatalapú irányítási formára vonatkozik, amely mérésére vonatkozó kísérleteket a következókben foglaljuk össze.

Kapcsolatiság, avagy a kapcsolati normák jelenléte

A kétoldalú kapcsolatokon keresztüli irányítás leírására először a szerződéses jog elméletéből kiindulva Macnail (1980) tett kísérletet, s a diszkrét-kapcso- 
latalapú kontinuumot a kapcsolati normák meglétével vagy hiányával írta le. A kapcsolatalapú irányítás empirikus kutatása nagyrészt erre a leírásra épül, bár megnevezésében sokszor eltér a kutatók szóhasználata. A kapcsolati normák kifejezést találhatjuk meg Heide és John (1992) vagy Jap - Ganesan (2000) munkáiban, a kapcsolatiság szót használja Noordevier - John és Nevin (1990) és Fink - Edelman - Hatten (2006), a kooperáció kifejezést alkalmazza Kalafatis - Sarpong - Sharif (2005), míg Geyskens - Steenkamp - Kumar (2006) a kapcsolati irányítás fogalmát használja.

Látható, hogy már a fogalom megnevezése is igen változatos a szakirodalomban, még inkább elmondható ez az empirikus kutatásokban alkalmazott mérési konstrukció kialakításáról. Az egyik elsô kísérlet Noordevier - John - Nevin (1990) nevéhez fúződik, akik öt tényezôn keresztül próbálták mérhetővé tenni a konstrukciót. Kapcsolatiság dimenziói kutatásuk alapján a következók:

- a szállító rugalmassága,

- a szállító segítókészsége, támogatása,

- a szállítónak nyújtott információ mennyisége és minősége,

- a szállító ellenôrizhetősége, és

- a jövoobeni kapcsolat feltételezése.

Ezek a változók vizsgálják a szállítót és a vevoót is, kérdéses azonban, hogy ezek a tényezók mennyiben mérhetốk jól, illetve, hogy nem maradtak-e ki fontos tényezôk (mint például a kommunikáció módja). Másrészról érdekes kérdés, amelyet a kutatók nem magyaráznak meg, hogy miért nem mindkét félre vonatkozóan vizsgálják a rugalmasságot, információcserét stb. Felvetődhet az a probléma is, hogy vajon a szállító ellenôrizhetôsége, illetve a jövoobeni kapcsolatra vonatkozó elvárások vajon valóban a kapcsolatiság-konstrukció meghatározói-e, vagy annak eredménye. Mindazonáltal, hogy a kapcsolatiság mérése rendkívül összetett feladat, az idézett kutatás annyiban úttörő, hogy elsóként kísérli meg mérhetôvé tenni a konstrukciót.

A kapcsolati normák hatásának elemzésére Heide és John (1992) három változóval operacionalizálja a kapcsolati norma elméleti konstrukcióját: rugalmasság, információcsere és segítókészség. Ezt a három változót az előzőekben bemutatott Noordevier et al. (1990) kapcsolatiság-konstrukciójából alkották, az ott bemutatott öt változóból hármat kiemelve. Habár ez a három változó az adott kutatásban a kapcsolati normák mérésére szolgál, tartalmát tekintve magát a kapcsolatiságot, a kapcsolatalapú irányítást fejezi ki.
Ugyanezt a három faktort használja Lusch - Brown (1996), megnevezésükben azonban kapcsolati viselkedés (relational behavior) a konstrukció elnevezése, s arra vonatkozik, hogy vajon viselkedésükben követik-e a kapcsolati normákat a vállalatok.

Valójában mind a három idézett kutatás magát a kapcsolatot, illetve a kapcsolati struktúrát (governance structure) igyekszik mérni, ezért eredményeik jól hasznosíthatóak saját kapcsolatiság-konstrukciónk kialakításában.

Értelmezésünkben a kapcsolatiság egy hosszú távú, kölcsönösségen alapuló kétoldalú viszony (Dwyer - Schurr - Oh, 1987; Heide, 1994), ahol a felek nem az egyik fél által kényszerített, és éppen ezért hierarchikusnak mondható kapcsolatban vesznek részt (legyen az akár a williamsoni hierarchia, akár Heide egyoldalú irányítású kapcsolata (Heide, 1994), hanem a kölcsönös érdekek alapján önkéntesen vállalt, és a bemutatott normák által szabályozott kapcsolatot alakítják ki egymással. A különbség a kettő között az, hogy az egyik kényszerített kapcsolat, míg a másik önkéntesen vállalt. Valószínúsíthető, hogy a kétféle kapcsolat eltér egymástól, más lesz az atmoszféra (Hakansson, 1982), mások lesznek az eredménytényezők, s hogyha Levitt már-már anekdotikussá vált házassághasonlatát használjuk (Levitt, 1983), akkor az egyik a „,kényszerházasság”, a másik a „szerelemházasság” példájával írható le.

Bankok és vállalatok kapcsolatának specialitása, hogy az tagsági viszonyon alapuló, folyamatos kapcsolat (Lovelock, 1983). A tranzakciós kapcsolatnak tehát elvileg ebben a viszonyban nincs létjogosultsága. A gyakorlati tapasztalat mégis azt mutatja, hogy a bankok kétféleképpen viselkedhetnek (Keltner, 1995; Moriaty - Kimball - Gay, 1983). Bár ügyfelükkel fenntartott kapcsolatuk elvileg folyamatos, mégis tranzakciós szemléletrôl beszélünk, amikor a bankon belül fő hangsúlyt a termékenkénti profitabilitás kapja, és nem az ügyfél-csoportonkénti, amikor az új vevók megszerzése nagyobb prioritást élvez, mint a már meglévook magasabb szintú kiszolgálása, illetve általánosságban elmondható a bank és a vállalat kapcsolatáról, hogy az esetenkénti, a kapcsolattartáshoz szükséges minimális kommunikációra korlátozódik.

A másik fontos tényezô, hogy a bankok és vállalatok kapcsolatában a williamsoni hierarchia kialakítására igen ritka esetben kerülhet sor, ez fóleg abban a helyzetben történhet meg, amikor a bank követeléseit más formában már nem tudja behajtani, csak úgy, hogy azért cserébe tulajdonrészt kap a vállalatból. Noha a magyarországi gyakorlatban ez a tranzakció nem ismeretlen, mégsem tekinthető jellemzőnek, s fooként nem tekinthető a kapcsolatok céljának. 
E megfontolások alapján a kutatásunkban vizsgált kapcsolatiságváltozó definíciónk szerint a bankok és vállalatok között kialakult kapcsolatok jellemzésére szolgál. Kutatásunkban a bank-vállalat között kialakított kétoldalú, hosszú távú kapcsolat - kapcsolatiság - latens változó, s három mérhetô változóval írható le: a partnerek rugalmassága, az információcsere és a segítốkészség. Ezek sorrendben a következôt jelentik:

A rugalmasság azt a kétoldalú elvárást jelenti, hogy a felek a környezeti tényezók változásának megfelelően alkalmazkodnak a mindenkori helyzethez egymás érdekeinek megfelelóen.

Az információcsere azt jelenti, hogy a felek kölcsönösen elvárják, hogy partnerük elózetesen informálja óket minden olyan eseményról, amely befolyásolhatja kapcsolatukat, illetve hasznos lehet a másik fél számára. Az információk cseréje kölcsönös, önkéntes és gyakran informális.

A segitókészség azt jelenti, hogy mindkét fél nagy értéket tulajdonít az adott kapcsolatnak. Ez kifejezetten a kapcsolat fenntartására szolgáló akciókat jelenti.

A kapcsolatiság latens változót a bemutatott három faktor összetételeként írhatjuk le. A kapcsolatiság két végpontja is kirajzolódott előttünk:

- Erős a kapcsolatiság a bank és a vállalat között, ha a felek kölcsönösen informálják egymást a kapcsolatot érintő eseményekról, rugalmasan reagálnak egymás kéréseire, ha a felek kölcsönösen nagy jelentőséget tulajdonítanak a közöttük fennálló kapcsolatnak, és a kommunikációra az együttmúködés (gyakori, informális, kétoldalú, önkéntes) jellemző:

- Gyenge a kapcsolatiság, ha a felek rugalmatlanok, ragaszkodnak az előzetesen kialakított feltételekhez, ha a kapcsolatnak nem tulajdonítanak különösebb jelentôséget, és a kommunikációra jellemző a formalitás, egyoldalúság, valamint a kényszerú információkra korlátozódó kommunikáció.

Kutatásunkban a fent bemutatott kapcsolatiság-változót operacionalizáltuk, s mérésére egy 19 elemból álló skálát fejlesztettünk ki. A kérdésekre a vállalat pénzügyi vezetôje válaszolt, $\mathrm{s}$ a konkrét bankra vonatkozó kérdéseket mindig a vállalat életében legfontosabb szerepet játszó bankra töltötte ki.

$\mathrm{Az}$ adatok elemzése során két fố célt tüztünk ki magunk elé: egyrészt vizsgálni kívántuk a magyarországi bankok vállalatokkal fenntartott kapcsolatának jellemzőit központi konstrukciónk, a kapcsolatiság segítségével. Cikkünkben nemcsak a jelenlegi állapotot mutatjuk be, hanem elôző kutatási eredményeinket felhasználva a kapcsolatok alakulásának tendenciáit is nyomon követhetjük a különböző időpontokban kapott eredmények egybevetésével.

A kutatás másik fontos célja magának a konstrukciónak az elemzése, hiszen annak mérése, amint azt az elózóekben bemutattuk, nem tekinthetô széles körben elfogadottnak. Fontosnak tartjuk azt is megjegyezni, hogy a skálafejlesztés lényeges eleme a tudományos marketingkutatásnak, s ahogy arra Kalafatis és tsai (2005) empirikus bizonyítékot is adtak, a skálák rutinszerú másolása sokszor nem követhetô, különösen eltérô kulturális közegben.

A következô részben tehát e kérdések elemzésével kívánjuk bemutatni, hogy hogyan írható le a mintában szereplő vállalatok kapcsolata bankjukkal, menynyire jellemezhetóek a magyarországi bankok hosszú, kétoldalú kapcsolatokra törekvő szolgáltatóként. Az eredmények bemutatásának második része magával a konstrukcióval foglalkozik: mennyiben alkalmazható az általunk használt skála a magyar bank-vállalat kapcsolatok leírására.

\section{Eredmények}

Mivel a versenyképesség-kutatás 2004-ben immáron harmadszor zajlott le, ezért eredményeink ismertetésekor lehetôségünk van nemcsak keresztmetszeti, hanem longitudinális összehasonlításra is. Ennek különösen az 1999-es és 2004-es adatok esetében van jelentôsége, mivel itt a megkérdezett vállalati kör nagyon hasonló paraméterekkel írható $\mathrm{le}^{2}$, ezért elsősorban e két időpont eredményeit fogjuk összevetni. Érdekes összehasonlításra ad lehetőséget egy 1998-as hasonló témában folyt kutatásunk, ahol a minta közép- és nagyvállalatokat tartalmazott, így lehetôséget ad arra is, hogy néhány esetben az eltérô vállalatméret befolyását is vizsgáljuk (Kenesei - Bauer, 1998).

Eredményeink közül elsóként a vállalatok elégedettségére ${ }^{3}$ vonatkozó kérdést szeretnénk bemutatni, ami alapján elmondhatjuk, hogy a vállalatok alapvetóen elégedettek fó bankjukkal, hiszen a 4,07-es átlag egy jó megítélést jelez. Ez azt is jelenti, hogy a piac viszonylag megnyugodott, $\mathrm{s}$ a vállalatoknak mostanra sikerült azt a bankot kiválasztaniuk, amely megfelel elvárásaiknak, s jó szolgáltatást nyújt, bár a tökéletestől elmaradnak. Ezek után nézzük a konkrét kapcsolatra vonatkozó kérdések eredményeit.

\section{Banki kapcsolatok száma}

2004-ben a vállalatok átlagosan 3,2 bankkal tartottak fönn kapcsolatot, amelyból 2,2 tekinthetô számlavezető banknak. Ez az adat összhangban van előző 
kutatásainkkal is, ahol a középvállalatok hasonló számú banki kapcsolatokról adtak számot. Összehasonlítva viszont egy nagyvállalati mintával, jóval kevesebb mind a számlavezetô, mind a nem számlavezetô bankok száma (1. táblázat).

1. táblázat

Banki kapcsolatok száma

\begin{tabular}{|l|l|c|c|}
\hline \multicolumn{2}{|l|}{} & \multicolumn{1}{|c|}{$\begin{array}{c}\text { Banki } \\
\text { kapcsolatok } \\
\text { száma }\end{array}$} & $\begin{array}{c}\text { Ebból } \\
\text { számla- } \\
\text { vezetó }\end{array}$ \\
\hline \multicolumn{2}{|c|}{ VK 1999 } & 3,39 & 2,17 \\
\hline \multicolumn{2}{|l|}{ VK 2004 } & 3,22 & 2,24 \\
\hline \multirow{2}{*}{$\begin{array}{c}\text { 1998-as } \\
\text { kutatás* }\end{array}$} & középvállalatok & 3,17 & 1,85 \\
\cline { 2 - 4 } & nagyvállalatok & 8,55 & 4,12 \\
\hline
\end{tabular}

* Forrás: Kenesei - Bauer, (1998)

Nyilvánvaló, hogy a bankok számának van egy optimális értéke, amely fölött már nem érdemes új kapcsolatokat létesíteni a túlzott adminisztrációs teher miatt. Ha viszont csak egy bankkal vannak a vállalatok kapcsolatban, akkor nagyon is kiszolgáltatottnak érezhetik magukat. A minta legtöbb vállalata így gondolkodik, amit az mutat, hogy egy bankja csupán a vállalatok 18\%-ának van, 2 és 5 között 72\%, míg 6 vagy annál több banki kapcsolattal 10\% rendelkezik. Még inkább igaz ez a számlavezetố bankokra, hiszen a vállalatok 70\%-a maximum 2 banknál vezettet számlát. Az, hogy a számlavezetố bankok száma jóval kevesebb, mint az általános banki kapcsolatoké, arra utal, hogy a bankok között valóban van verseny, s a vállalatok nem minden szolgáltatást vesznek a számlavezetôjüktő́l igénybe, hanem körülnéznek a piacon, s a számukra az adott tranzakció (pl. hitelfelvétel) szempontjából legelőnyösebb ajánlatot választják. Ez némileg tranzakció-orientáltabb szemléletet tükröz.

\section{Kapcsolatok jellemzói}

A bank-vállalat kapcsolatokat az elóbbiekben bemutatott három dimenzióban vizsgáltuk, amelyek közül először az információk cseréjére vonatkozó változókat elemezzük.

\section{Az információcsere}

Az információk cseréje, illetve maga a kommunikáció is többféle dimenzióval írható le (Mohr - Nevin, 1990; Mohr - Fisher - Nevin, 1996), amelyek közül az információáramlás gyakoriságát, a kommunikáció módját (formális-informális), az információáramlás irányultságát (azaz mennyire egy- vagy kétoldalú) és tartalmát, s végül azt vizsgáltuk, hogy mennyire korlátozódik a kényszerítô jellegú információkra.
Az információáramlás gyakoriságát tekintve elmondhatjuk, hogy a pénzügyi vezetók elég élénknek tartják a bankkal való kapcsolatukat, ami valószínúleg annak is köszönhető, hogy a legtöbb bank ma már elektronikus formában tartja a vállalati ügyfeleivel a kapcsolatot. Míg a 2004-es mintában a vállalatok 4,02 -es átlagértéket adtak arra vonatkozóan, hogy milyen gyakori az információk cseréje, addig '99-ben ezt még csak 3,8-ra értékelték. Ez jelentheti egyrészt a bankok aktivitásának élénkülését, és jelentheti azt is, hogy egyre elterjedtebb az elektronikus kapcsolattartás.

\section{Az információcsere irányultsága és jellege}

A vállalat-bank kapcsolatokat jól leírja, hogy menynyire önkéntes, illetve kényszerítố jellegú a kapcsolat a felek közt. Az erre vonatkozó eredményeket a 2. táblázatban foglaltuk össze.

\section{Bankok}

2. táblázat

és vállalatok közötti információcsere jellege*

\begin{tabular}{|l|c|c|}
\hline Az információcsere jellege & Önként & Kérésre \\
\hline Bank ad információt & $3,36(3,16)$ & $4,47(4,39)$ \\
\hline Vállalat ad információt & $3,26(3,00)$ & $4,61(4,45)$ \\
\hline
\end{tabular}

* Zárójelben az 1999-es adatok

A 2. táblázat azt mutatja be, hogy a vállalatok menynyire tartják magukra jellemzőnek, hogy kérésre $(4,61)$, illetve önként $(3,26)$ a bank számára szükséges információkat megadják, valamint azt, hogy mennyire tartják a bankra jellemzónek, hogy a vállalat számára szükséges információkat kérésre $(4,47)$ illetve önként $(3,36)$ megadják. Ami rögtön szembetúnik a táblázatból, hogy a kényszerító jellegú információcsere sokkal jellemzóbb a bank-vállalat kapcsolatokra, mint az önkéntes. Ez azt is mutatja, hogy ma még nem tekinthetjük a két fél közötti kapcsolatot a saját szempontunkból igazán szorosnak. Érdekes azt is megfigyelni, hogy míg a kényszerítő jellegú információközlésben a vállalatok magukat tartják ,jobbnak”, addig az önkéntes információáramoltatásban a bankokat. Ez megint csak arra utal, hogy a vállalatok nem bíznak meg teljesen banki partnerükben, éppen csak annyit mondanak magukról, amennyi szükséges.

Pozitív tendenciára utal a bank-vállalat kapcsolatokban, hogy a '99-es válaszokhoz mérten mind a négy esetben javulás történt, mind kérésre, mind önként jellemzôbbnek találták az információk cseréjét a vállalatok.

\section{Az információcsere formalizáltsága}

Az információcsere formalizáltsága, azaz annak a mértéke, hogy milyen mértékben adnak egymásnak a partnerek információkat szerződésen kívül is, szintén 
méri a kapcsolat minôségét. Mintánkban a vállalatok közepesre értékelték ezt a jellemzőt $(3,5)$, azaz bizonyos esetekben csak a szerződésben foglaltaknak megfelelően váltanak egymással információt, bizonyos esetekben pedig eltérnek ettől, s azon túl is (vagy az alatt) adnak információt.

\section{Az információcsere tartalma}

Az információcsere tartalma természetesen szintén összefügg az önkéntes-kényszerítő jelleg változóval -, hiszen vannak olyan információk, amelyeket szerzôdés szerint közölni kell a partnereknek egymással, de vannak olyan információk is, amelyek közlése csupán a felek jóindulatán múlik -, s abban segíthet, hogy a kapcsolat mélyebb, és elkötelezettebb legyen. Erre vonatkozó kérdéseinkre a következô eredményeket kaptuk.

A bank egyik legfontosabb információja a vállalatok felé a számlaegyenleg. Ezt természetesen minden vállalat megkapja, bár a 4,82-es átlag arra utal, hogy néha még ezzel az alapvetô információval is gond lehet. A banki kondíciók szintén fontos információnak számítanak, hiszen ez jelenti a szolgáltatások árát, ezért nyilvánvaló, hogy a vállalatok szeretnének információt kapni róla. Mégis a 4,1-es átlag arról tanúskodik, hogy vannak bankok, amelyek szeretik - ha nem is eltitkolni, de - elhallgatni, hogy változtattak a szolgáltatás árán. Gyakori eset, hogy csupán a számlalevélen jelenik meg egy közlés arra vonatkozóan, hogy változtak a feltételek, de a konkrét változásokról már nem tájékoztatnak. Ez a fajta nagyon is „,bankos” kezelése az árinformációknak sokszor rossz hatással van a bank-vállalat kapcsolatra, és nem segíti elő a kölcsönösséget. Az információcsere egy következó szintje, amikor a bank nemcsak a „kötelezô” információkkal látja el ügyfelét (számla állása, kondíciók), hanem olyan tényezókre is felhívja a figyelmét, amely befolyással lehet az ügyfél üzletmenetére. Erre szolgálhat a banki hírlevél, de sokkal személyesebb módon is történhet az információcsere, hiszen az ügyfélreferens még ,vállalatra szabottabb” információt is nyújthat, mint az egyen hírlevél. Kérdésünkben a pénzügyi piac vállalatot érintő változásaira vonatkozó információkra kérdeztünk rá, s a bankok nem bizonyultak túlzottan segítókésznek ezen a téren, csupán 3,3-as átlagot kaptak.

Még kevésbé jellemző az információáramlás a vállalatoktól a bankok felé. Erre vonatkozóan is háromféle típusú információt vizsgáltunk: a vállalat piaci eredményeire, a vállalat pénzügyi helyzetére és a szolgáltatások iránti igényeire vonatkozóan. Míg az elôzố kettő nyilvánvalóan a bankot segítheti az eredményes kihelyezési politikában, addig az utóbbi segítheti a megfelelő szolgáltatáscsomag kialakításában. A kény- szerítő jelleget tekintve is van különbség a három fajta információ között, míg a pénzügyi helyzetról általában a bank kér információt, addig a másik két információ nyújtása sokkal inkább a vállalatra bízott. Ennek megfelelően is alakultak az eredmények (összhangban a 2. táblázatban megjelent eredményekkel). A vállalatok saját pénzügyi helyzetükról szóló információcsere intenzitását 3,5-es átlagra értékelték, míg a piaci helyzetükre és a szolgáltatások iránti igényeikre vonatkozókat 3,3-es átlagértékkel jelölték meg. Látható, hogy ezek az értékek messze elmaradnak a bankok információnyújtási hajlandóságától, amit okoz egyrészt természetesen az információk eltéró természete, másrészt az információcsere egyoldalúsága (3. táblázat).

3. táblázat

\section{Az információcsere tartalma}

\begin{tabular}{|c|l|c|}
\hline $\begin{array}{c}\text { Az informá- } \\
\text { ció szolgál- } \\
\text { tatója }\end{array}$ & \multicolumn{1}{|c|}{ Az információ típusa } & Átlag \\
\hline \multirow{4}{*}{ Bank } & Számla állása & 4,8 \\
\cline { 2 - 3 } & Szolgáltatások, kondíciók & 4,1 \\
\cline { 2 - 3 } & $\begin{array}{l}\text { Pénzügyi környezet vállalatot is } \\
\text { érintố változásai }\end{array}$ & 3,3 \\
\hline \multirow{3}{*}{ Vállalat } & Vállalat pénzügyi helyzete & 3,5 \\
\cline { 2 - 3 } & Vállalat piaci eredményei & 3,3 \\
\cline { 2 - 3 } & Szolgáltatások iránti új igényei & 3,3 \\
\hline
\end{tabular}

\section{Rugalmasság}

A következő változócsoportunk a kapcsolat rugalmasságára vonatkozik, s azt tartalmazza, hogy menynyiben képesek a partnerek rugalmasan reagálni a környezeti, illetve a partner helyzetében fennálló változásokra. A változásokra való reagálást többek között az teszi lehetôvé, hogy a kapcsolatnak vannak informális elemei, s nemcsak a szerződésben előzetesen rögzített feltételek mellett hajlandók a kapcsolat résztvevôi dolgozni. A banki szolgáltatások általában az erősen formalizált kapcsolatok közé tartoznak, mégis lehetnek olyan elemei, amelyek a felek rugalmasságán múlnak, s például a banki referensen múlik, hogy a vállalat javára eltér az eredeti szerződéses feltételektől. Ilyen példa lehet a garancianyújtás a vállalati ügyfelek részére. Általában a bankok a szerződésben rögzítik, hogy csak bizonyos feltételek teljesítése mellett, egy bizonyos idő́n belül (pl. egy-két nap) adnak a vállalat számára garancialevelet. Amennyiben azonban a bank jó kapcsolatban van ügyfelével, eltérhet ettól, s egy-egy sürgós esetben (mivel ismeri a vállalatot) néhány órán belül kiadhatja a szükséges papírokat. Ez a fajta rugalmasság természetesen csak egy jól múkö- 
dô kapcsolatban érhetố tetten, ezért is mérjük ezzel a változóval (is) a bank-vállalat kapcsolat erósségét. A bank rugalmasságára vonatkozó átlagérték $(3,55)$ nem tekinthetô különösen magasnak, jelezve, hogy van javítanivaló a bankok rugalmasságán.

Kérdôívünkben két kérdés vonatkozott a kapcsolat informális elemeire (ami lehetôvé teszi a rugalmas megoldásokat), s a két kérdés teljes összhangban azt mutatja, hogy kevéssé jellemzóek az informális megállapodások és szóbeli egyezségek a bankok és vállalati ügyfeleik kapcsolatára. Míg arra a kérdésre, hogy vannak-e szóbeli megállapodások, az átlagérték 2,5 volt, arra a kérdésre, hogy a kapcsolat minden eleme írásban rögzítette, 3,6 volt a válaszok átlagértéke. Ezek a válaszok arra utalnak, hogy bár nem jellemzó, de mégis vannak területek, ahol lehetséges még a banki üzletmenetben is a kapcsolat rugalmatlanságának enyhítése.

\section{Segitókészség}

A segítókészség dimenzió a bank-vállalat kapcsolatban azt jelenti, hogy mennyire érzékeli a vállalat azt, hogy a bank nemcsak a saját hasznát keresi az adott kapcsolatban, hanem szolgáltatásaival és a kapcsolattartón keresztuil munkatársaival mindig figyelembe veszi a vállalat érdekeit is, hiszen ez lehet az alapja egy hosszú távú, kétoldalú kapcsolatnak. A kérdések is erre vonatkoztak: mennyire gondolják a vállalatok a bankjukról, hogy figyelembe veszik az ô érdeküket is, menynyiben segítenek pénzügyi problémáik megoldásában, illetve mennyire segítenek az üzletmenetben. A vállalatok véleménye ebben nem túl pozitív bankjukról, hiszen a kérdésekre 3,3-3,5-ös átlagértékeket jelöltek meg, ami azt jelzi, hogy a kapcsolat közös érdeken alapuló volta még nem nyert teret.

\section{A kapcsolatiság-konstrukció faktorelemzése}

A bank-vállalat kapcsolatok elemzésére alkalmazott változók hipotézisünk szerint három faktorba sorolhatók, amelyek takarják a három fó elemzési csoportot. Míg a kapcsolatok gyakorlati értékelésére a fent bemutatott elemzés során alkalmazott változók alkalmasak, addig a tudományos elemzések és a további modellalkotás szempontjából fontosnak tartjuk magának a latens kapcsolatiság-konstrukciónak is az elemzését. Módszerünk a faktorelemzés, amely segítségével az összetartozó változó-elemeket (itemeket) kívánjuk meghatározni. A faktorelemzés eredményét a 4 . táblázat mutatja be (4. táblázat).

A faktoranalízis eredménye bizonyos szempontból meglepó, más szempontból azonban elöre várható eredményeket adott. Ami azonnal látszik, hogy a formalitásra (ezen keresztül a rugalmasságra) vonat-
4. táblázat

\section{A kapcsolatiság-konstrukció faktormegoldása}

\begin{tabular}{|c|c|c|c|}
\hline Változólista & 1. faktor & 2. faktor & 3. faktor \\
\hline $\begin{array}{l}\text { Bankunk minden infor- } \\
\text { mációt megad, kérni kell }\end{array}$ & 0,765 & $-5,844 \mathrm{E}-02$ & $8,724 \mathrm{E}-02$ \\
\hline $\begin{array}{l}\text { Bankunk önként megad } \\
\text { minden információt }\end{array}$ & 0,623 & 0,258 & $-2,113 \mathrm{E}-02$ \\
\hline $\begin{array}{l}\text { Vállalatom kérésre megad } \\
\text { minden információt }\end{array}$ & 0,519 & $2,155 \mathrm{E}-02$ & 0,195 \\
\hline $\begin{array}{l}\text { Bankunk figyelembe veszi } \\
\text { a mi érdekeinket is }\end{array}$ & 0,595 & 0,426 & $-1,893 \mathrm{E}-02$ \\
\hline $\begin{array}{l}\text { Bankunk általában } \\
\text { rugalmasan reagál }\end{array}$ & 0,601 & 0,302 & $-0,141$ \\
\hline $\begin{array}{l}\text { Bankunk segíti vállalatom } \\
\text { üzletmenetét }\end{array}$ & 0,675 & 0,295 & $-0,134$ \\
\hline $\begin{array}{l}\text { Bankunk informál } \\
\text { a számlánk állásáról }\end{array}$ & 0,288 & $6,802 \mathrm{E}-02$ & 0,233 \\
\hline $\begin{array}{l}\text { Bankunk informál } \\
\text { a kondíciók változásáról }\end{array}$ & 0,412 & 0,335 & 0,196 \\
\hline $\begin{array}{l}\text { Bankunk informál } \\
\text { a pénzügyi változásokról }\end{array}$ & 0,512 & 0,342 & $-2,371 \mathrm{E}-02$ \\
\hline $\begin{array}{l}\text { Banki referens mindig } \\
\text { naprakész információtt ad }\end{array}$ & 0,645 & 0,291 & $-0,102$ \\
\hline $\begin{array}{l}\text { Banki referens olyan } \\
\text { problémákat is jelez, } \\
\text { ami nem kötelezó }\end{array}$ & 0,584 & 0,171 & $-0,338$ \\
\hline $\begin{array}{l}\text { Vállalatom és bankunk } \\
\text { közti információcsere } \\
\text { gyakori }\end{array}$ & $\mathbf{0 , 5 2 0}$ & 0,486 & $-6,221 \mathrm{E}-03$ \\
\hline $\begin{array}{l}\text { Vállalatom önként megad } \\
\text { minden információt a } \\
\text { banknak }\end{array}$ & 0,325 & 0,546 & $-2,000 \mathrm{E}-02$ \\
\hline $\begin{array}{l}\text { Vállalatom informálja } \\
\text { pénzügyi helyzetéról a } \\
\text { bankot }\end{array}$ & 0,175 & 0,832 & $5,842 \mathrm{E}-02$ \\
\hline $\begin{array}{l}\text { Vállalatom informálja } \\
\text { a piaci eredményeiról a } \\
\text { bankot }\end{array}$ & 0,103 & 0,864 & $-3,537 \mathrm{E}-02$ \\
\hline $\begin{array}{l}\text { Tájékoztatjuk a bankot } \\
\text { szolgáltatások iránti } \\
\text { igényekról }\end{array}$ & 0,244 & 0,737 & 0,133 \\
\hline $\begin{array}{l}\text { Az információk cseréje } \\
\text { szerző́dés szerint }\end{array}$ & $-0,117$ & 0,205 & $\mathbf{0 , 5 2 7}$ \\
\hline $\begin{array}{l}\text { Kapcsolatunk minden } \\
\text { eleme írásban rögzített }\end{array}$ & 0,199 & $9,045 \mathrm{E}-02$ & 0,815 \\
\hline $\begin{array}{l}\text { Bankunkkal kapcsolatban } \\
\text { van szóbeli egyezség }\end{array}$ & 0,162 & 0,299 & $-0,695$ \\
\hline
\end{tabular}

Varimax rotációval, 50\% magyarázott kumulált szórással 
kozó változók egy csoportba kerültek, tehát úgy túnik, ez egy jól múködő faktor. Az utolsó változó negatív értéke jelzi, hogy ez egy ellentétesen kódolt változó. A második faktor úgy túnik, hogy az információcsere vállalati oldalát sứríti magába, hiszen ide került minden olyan kérdés, amely a vállalatok részéról a bank felé irányuló kommunikációra vonatkozik. S végül a

5. táblázat

\section{kapcsolati változók faktoranalízise}

\begin{tabular}{|l|c|c|c|}
\hline Változólista & $\mathbf{1 . ~ f a k t o r}$ & $\mathbf{2 . ~ f a k t o r}$ & 3. faktor \\
\hline $\begin{array}{l}\text { Bankunk önként megad } \\
\text { minden információt }\end{array}$ & $\mathbf{0 , 5 9 8}$ & 0,211 & 0,231 \\
\hline $\begin{array}{l}\text { Bankunk általában } \\
\text { rugalmasan reagál }\end{array}$ & $\mathbf{0 , 7 3 6}$ & $9,496 \mathrm{E}-02$ & 0,127 \\
\hline $\begin{array}{l}\text { Bankunk segíti vállalatom } \\
\text { üzletmenetét }\end{array}$ & $\mathbf{0 , 8 0 5}$ & 0,128 & $5,146 \mathrm{E}-02$ \\
\hline $\begin{array}{l}\text { Banki referens mindig } \\
\text { naprakész információt ad }\end{array}$ & $\mathbf{0 , 6 3 1}$ & 0,419 & $9,170 \mathrm{E}-03$ \\
\hline $\begin{array}{l}\text { Banki referens olyan } \\
\text { problémákat is jelez, ami } \\
\text { nem kötelezó }\end{array}$ & $\mathbf{0 , 5 5 8}$ & 0,466 & $-0,162$ \\
\hline $\begin{array}{l}\text { Bankunk figyelembe veszi } \\
\text { a mi érdekeinket is }\end{array}$ & $\mathbf{0 , 7 5 7}$ & 0,148 & 0,101 \\
\hline $\begin{array}{l}\text { Bankunk informál a } \\
\text { pénzügyi változásokról }\end{array}$ & $\mathbf{0 , 6 2 3}$ & $-3,776 \mathrm{E}-03$ & 0,390 \\
\hline $\begin{array}{l}\text { Bankunk informál a } \\
\text { kondíciók változásáról }\end{array}$ & 0,420 & $-7,377 \mathrm{E}-03$ & $\mathbf{0 , 7 0 0}$ \\
\hline $\begin{array}{l}\text { Bankunk informál } \\
\text { a számlánk állásáról }\end{array}$ & $-3,985 \mathrm{E}-02$ & 0,205 & $\mathbf{0 , 7 7 8}$ \\
\hline $\begin{array}{l}\text { Bankunk minden informá- } \\
\text { ciót megad, kérni kell }\end{array}$ & 0,308 & $\mathbf{0 , 7 3 9}$ & 0,172 \\
\hline $\begin{array}{l}\text { Vállalatom kérésre megad } \\
\text { minden információt }\end{array}$ & $3,280 \mathrm{E}-02$ & $\mathbf{0 , 8 3 7}$ & 0,120 \\
\hline
\end{tabular}

Varimax rotációval, 60\% magyarázott kumulált szórással

legnagyobb faktor, az összes olyan változót magában foglalja, amely a kapcsolat banki részére vonatkozik. Itt vannak tehát a bank által irányított információk, a rugalmasságra és a segítókészségre vonatkozó változók (illetve egy, a vállalat által adott információ, amely azonban a bank részéról kényszerítő jellegú, tehát a bank kezdeményezi).

Úgy túnik ezek alapján, hogy a vállalatok nem a kapcsolati elemek alapján értékelik a bank-vállalat kapcsolatukat, hanem az alapján, hogy felőlük vagy a bank felól indulnak-e a kapcsolatra vonatkozó akciók. Ez azt is jelzi, hogy a kapcsolat ma még nem tekinthetô kétoldalúnak, sokkal jellemzóbb az egyoldalú akci- ók megléte. Mivel az első faktor ilyen jelentős számú változót foglal magában, érdemesnek tartottuk megvizsgálni ezt az egy faktort is egy újabb faktoranalízis segítségével, hiszen továbbra is választ szeretnénk kapni arra, hogy vajon elválnak-e az általunk fontosnak tartott dimenziók egymástól (5. táblázat).

Az eredmény ezúttal már jobban megfelel a várakozásainknak, hiszen egy faktorba kerültek a bank segítőkészségére és rugalmasságára vonatkozó változók, s a másik két faktorba kerültek az információcserére vonatkozóak. Ez utóbbi kettó közül az egyik a banki „kötelezô” információkra vonatkozó változókat, míg a másik a kényszerító jellegú információcserére vonatkozó változókat tömöríti. Ismét az elsố faktorban súrúsödnek a változók, itt szerepel az összes olyan item, amely arra vonatkozik, hogy a bank milyen szolgáltatást nyújt, azaz mennyire veszi figyelembe a vállalat érdekeit, mennyire rugalmas a kapcsolatban, milyen önkéntes információkat ad (tehát a vállalatot segító információt). Úgy túnik tehát a magyar vállalati pénzügyi vezetốk értékelése alapján, hogy egyfajta holisztikus képet alkotnak bankjukról, s nem részleteiben értékelik a kapcsolatot, hanem az egész kapcsolatról van vagy pozitív, vagy negatív értékelésük. Ez az eredmény egyébként megerősíti előző kutatási eredményeinket (Kenesei, 2004), ahol hasonlóképpen egy faktorba rendeződtek a segítókészségre és rugalmasságra vonatkozó kérdések. Összefoglalóan tehát azt mondhatjuk, hogy a magyarországi bank-vállalat kapcsolatok még nem teljesedtek ki olyan mértékben, hogy az amerikai, nyugat-európai eredményekhez hasonlóan alkalmazni tudjuk az ott múködő kapcsolati skálát, mivel a kapcsolatokat a magyar pénzügyi vezetốk nem részleteiben értékelik és elemzik, hanem egyfajta általános képet alkotnak róla.

Eredményeink alapján érdemesnek tartjuk a magyar sajátosságoknak megfelelően inkább az információcsere változójának alkalmazását, amely úgy túnik, jobban differenciálja a vállalat-bank kapcsolatokat, s a rugalmasság/segítókészség változó tömörítését, amely észlelése egyelőre még nem válik szét a vállalatok válaszaiban.

\section{Lábjegyzet}

${ }^{1}$ Kenesei Zsófia a BCE Marketing és Média Intézet, Marketing Tanszékének docense. E-mail: zsofia.kenesei@uni-corvinus.hu

${ }^{2}$ Fókuszban a verseny, Gyorsjelentés a 2004.évi felmérés eredményeirôl

${ }^{3}$ Az elégedettséget 5-ös skálán mértük, ahol 1 - egyáltalán nem elégedett 5 - nagyon elégedett

${ }^{4}$ A kérdőívben a kérdésekre 1-5-ig lehetett választ adni, ahol 1 egyáltalán nem jellemző; 5 - nagyon jellemzố választ jelentette. 


\section{Felhasznált irodalom}

Dwyer, F. R. - Schurr, P. H. - Oh,S. (1987): Developing Buyer-Seller Relationships. Journal of Marketing, 51 (April), 11-27. o.

Fink, R.C. - Edelman, L.F. - Hatten, K. J. (2006): Relational Exchange Strategies, Performance, Uncertainty, and Knowledge. Journal of Marketing Theory and Practice, Vol. 14, No.2, Spring, 139-153. o.

Geykens, I. - Steenkamp, J. E. M. - Kumar, N. (2006): Make, Buy, or Ally: a Transaction Cost Theory Meta-Analysis. Academy of Management Journal, Vol. 49, No. 3, 519543. o.

Heide, J. B. (1994): Interorganizational Governance in Marketing Channels. Journal of Marketing, 58 (January), 71-85. o.

Jackson, B. B. (1985): Build Customer Relationships that Last. Harvard Business Review, Nov-Dec. 120-128. o.

Jap, S. D. - Ganesan, S. (2000): Control Mechanisms and the Relationship Life Cycle: Implications for Safeguarding Specific Investments and Developing Commitment. Journal of Marketing Research, Vol. XXXVII, May, 227-245. o.

Kalafatis, S.P. - Sarpong Jr, S. - Sharif, K. J. (2005): An examination of the stability of operationalisations of multi-item marketing scales. International Journal of Market Research. VO1 47, Issue 3, 255-266. o.

Keltner, B. (1995): Relationship Banking and Competitive
Advantage: Evidence from the U.S. and Germany. California Management Review, 37 (Summer), 45-72. o.

Kenesei, Zs. - Bauer, A. (1998a): A magyar kereskedelmi bankok tevékenységének marketingszempontú elemzése. I. Egy interjúsorozat tanulságai. Bankszemle, 5. 1-13. o.

Kenesei, Zs. - Bauer, A. (1998b): A magyar kereskedelmi bankok tevékenységének marketingszempontú elemzése. II. Egy kérdőíves felmérés tanulságai. Bankszemle, 6-7. 87-99. o.

Kenesei Zsófia (2004): A kapcsolati marketing jelentősége a kereskedelmi banki tevékenységben. Akadémia Kiadó, Budapest

Moriaty, R.T. - Kimball, R. C. - Gay, J. H. (1983): The Management of Corporate Banking Relations, Sloan Management Review, 24, 3-16. o.

Noordewier, T.G. - John, G. - Nevin, J. R. (1990): Performance Outcomes of Purchasing Arrangements in Industrial Buyer-Vendor Relationships. 54 (October), 80-93. o.

Rindfleisch, R. - Heide, J. B. (1997): Transaction Cost Analysis: Past, Present, and Future Applications. Journal of Marketing. Vol 61, October, 30-54. o.

Williamson, O.E. (1975): Markets and Hierarchies: Analysis and Antitrust Implications. New York: The Free Press. New York

Williamson, O. E. (1996): The Mechanisms of Governance. New York: The Free Press. New York

\section{O N T E N T S}

\section{STUdies AND ARTICLES}

\section{Chikán, Attila - Czakó, Erzsébet}

Hungarian Competitiveness from Enterprise

Perspective, 2004-2006.

\section{Bartók István}

Hungarian corporate governance at the EU accession

Zoltayné Paprika, Zita - Wimmer, Ágnes - Szántó, Richárd The managerial decision making and the competitiveness

\section{Demeter, Krisztina}

The trustees of the corporate success: joint examination of the corporate functional areas 29

\section{András, Krisztina - Juhász, Péter}

Financial performance of Hungarian enterprises, 1994-2004

\section{Kenesei, Zsófia}

Relational governance between Hungarian banks and their client companies 52 